\title{
IMPLEMENTASI PEMBUKUAN SEDERHANA PADA UMKM ANNA COLLECTION DI DESA PANGKALAN KECAMATAN PLERED KABUPATEN CIREBON
}

\author{
Erwin Budianto $^{1^{*}}$, Nurhana Dhea Parlina ${ }^{2}$ \\ ${ }^{1,2}$ Fakultas Ekonomi, Universitas Swadaya Gunung Jati \\ E-mail: ${ }^{1)}$ erwinbudiantodua@gmail.com
}

\begin{abstract}
Abstrak
UMKM atau Usaha Mikro Kecil dan Manengah merupakan salah satu penggerak ekonomi Negara Indonesia. Dari tahun ke tahun perkembangan UMKM di Indonesia semakin meningkat, hal itu ditandai dengan meningkatnya kontribusi UMKM terhadap PDB dan meningkatnya serapan tenaga kerja dari sektor UMKM. Namun, beberapa UMKM masih terkendala dalam masalah pembukuan belum tertata dan terencana dengan baik yang mengakibatkan nilai akhir laba rugi yang berbeda sesuai dengan fakta yang ada permasalahan dalam manajemen keuangan pembukuan yang mencatat setiap transaksi arus kas secara tertib dan terarah. Salah satu UMKM yang potensial tetapi masih belum berkembang adalah UMKM Anna Collection. Pembukuan yang dilakukan UMKM Ana Collection masih belum tertib dan terarah berakibat tidak adanya laporan laba rugi usahanya. Melalui kegiatan pengabdian kepada masyarakat ini diharapkan dapat memberi pemahaman pentingnya pencatatan keuangan dalam usaha dagang bagi UMKM. Pembukuan sederhana merupakan hal yang sangat penting didalam dunia Bisnis, banyak sekali manfaat yang di dapat apabila sebuah UMKM memiliki pembukuan yang teratur. Selain dapat digunakan sebagai patokan untuk melihat keuntungan yang didapat, dengan adanya pembukuan juga dapat pula para pebisnis mengetahui kerugian yang dialaminya.
\end{abstract}

Kata kunci: Pembukuan Sederhana, Manajemen Keuangan, Pengabdian Masyarakat, UMKM

\begin{abstract}
MSMEs, or Micro, Small, and Medium-Sized Enterprises, are a critical component of Indonesia's economy. Each year, the development of MSMEs in Indonesia accelerates, as seen by their increasing contribution to GDP and workforce absorption by the MSME sector. However, some MSMEs continue to be constrained by accounting issues that have not been well organized and planned, resulting in a different final profit and loss value in accordance with the fact that there are issues with accounting financial management, which records each cash flow transaction in an organized and directed manner. MSME Anna Collection is one of the MSMEs with potential but has not yet developed. The Ana Collection MSME's bookkeeping is still unstructured and undirected, hence in the absence of a profit and loss statement for the business. It is believed that this community service activity would foster a knowledge for the critical nature of financial records in trading operations for MSMEs. Simple bookkeeping is critical in the business sector; there are numerous benefits to an MSME that maintains regular bookkeeping. Apart from serving as a benchmark for determining profits, the availability of bookkeeping enables business owners to ascertain their losses.
\end{abstract}

Keywords: Simple Bookkeeping, Financial Management, Community Service, MSME 


\section{PENDAHULUAN}

UMKM atau Usaha Mikro Kecil dan Manengah merupakan salah satu penggerak ekonomi Negara Indonesia. Dari tahun ke tahun perkembangan UMKM di Indonesia semakin meningkat, hal itu ditandai dengan meningkatnya kontribusi UMKM terhadap PDB dan meningkatnya serapan tenaga kerja dari sektor UMKM. Akan tetapi perkembangan UMKM di Indonesia masih belum merata hingga ke daerah pelosok, salah satunya adalah daerah yang berada di Desa Pangkalan, Kecamatan Plered, Kabupaten Cirebon.

Desa Pangkalan merupakan daerah yang berada di Sebelah Barat Kota Cirebon. Berdasarkan data BPS Kabupaten Cirebon (2020), Desa Pangkalan memiliki luas wilayah 183.880 Ha. Selanjutnya lokasi Desa Pangkalan ke pusat kota Cirebon dapat dijangkau melalui dua alternatif. Pertama, melalui Jalur Cirebon - Indramayu dengan jarak 15,4 km, Kedua memalui jalur Cirebon - Bandung dengan jarak 17,3 km, meskipun lokasinya berada di Kabupaten Cirebon, tetapi untuk akses sangat dekat dengan kota Cirebon.

Berdasarkan data BPS Kabupaten Cirebon (2020), jumlah penduduk di desa Pangkalan sebanyak 5978 orang. Secara umum, profesi masyarakat Desa Pangkalan adalah sebagai petani, tetapi ada juga yang memiliki usaha sendiri atau berwirausaha meskipun dalam skala yang kecil. Salah satu UMKM yang potensial tetapi masih belum berkembang adalah UMKM Anna Collection.

UMKM Anna Collection merupakan usaha rumahan yang dijalankan oleh keluarga besar Bapak Muhammad Yatim yang bergerak dibidang penjualan busana muslim. Oleh karena itu di tahun 2000 bisnis busana muslim ini berjalan namun setelah itu dipindah tangankan oleh istri dan anaknya di tahun 2021.

Usaha UMKM Anna Collection ini sempat berhenti ditengah jalan akibat dari pemilik utama meninggal dunia oleh Almarhum Muhammad Yatim berkat kegigihan dan tekad anak satu satunya, usaha ini bangkit kembali sampai sekarang dilanjutkan oleh istri dan anaknya yaitu Nuryami dan Anah Tiyana.

Hal ini lah, yang melatar belakangi dari pendirian Anna Collection ini adalah bahwa setiap wanita menginginkan tampil beda, trendy dan fashionable serta update dalam bergaya dan berbusana dari setiap berbagai acara dan kesempatan serta kegiatan yang dilakukan.

Sistem usaha yang dijalankan oleh Anna collection adalah dengan membeli produk jadi dari Konveksi besar yang ada di kota Bandung, Jakarta dan Sebagian Kota Cirebon untuk dijual kembali hal ini menggunakan strategi penjualan putus untuk membeli barang dari suplier dan memasarkannya kepada konsumen akhir. Namun, sebagian sistem perdagangan berlandaskan kepercayaan dari si pemilik apabila kegiatan negosiasi dalam sistem pembayaran berdasarkan transaksi yang dilakukan adalah kebijakan dari Anna collection sendiri.

Segmen pasar yang ditargetkan dari usaha ini adalah dari berbagai macam golongan dari remaja maupun dewasa. Kesediaan ukuran yang ditawarkan dari M hingga XXXL apabila tidak dapat memenuhi ukuran dapat disediakan sesuai dengan permintaan dari konsumen atau pelanggannya.

Dampak inflasi sangat dirasakan dengan biaya operasional yang sejatinya memenuhi kebutuhannya secara efektiktif dan efisien (Gintings, 2011). Namun, terkadang karena covid 19 mempengaruhi keuntungan yang didapatkan dan tentunya hasil laporan keuangan laba rugi secara langsung mempengaruhi keuntunganpun akan menurun hal ini dihitung dari per 


\section{PORTAL RISET DAN INOVASI PENGABDIAN MASYARAKAT (PRIMA) \\ VOLUME 1 ISSUE 1 (2021)}

satuan keuntungan dari tiap kodi dari keunikan dilihat dari motif, design, bordiran dan jenis bahan.

Informasi tentang pembukuan belum tertata dan terencana dengan baik dari segi praktek dilapangan terkadang terkendala dalam hilangnya arsip kwitansi atau nota hilang pada saat transaksi dilakukan baik pengeluaran ataupun pemasukan dari tiap transaksi operasional sehingga sulit mengkalkulasi nilai nominal secara real dalam pelaporan. Sehingga akan mengakibatkan nilai akhir laba rugi yang berbeda sesuai dengan fakta yang ada permasalahan dalam manajemen keuangan pembukuan yang mencatat setiap transaksi arus kas secara tertib dan terarah. Masalah lainnya timbulnya kurangnya pemisahan antara kebutuhan pribadi dan keperluan bisnis. Hal ini adalah permasalahan dari manajemen keuangan yang terdapat dalam Anna Collection.

Banyak konsumen tertarik dengan produk yang ditawarkan Anna Collection, namun baru dari kalangan warga sekitar saja. Tetapi tidak menutup kemungkinan untuk kedepannya produk yang dimiliki UKM ini akan dapat dipasarkan ke luar wilayah kecamatan Plered. Walaupun kegiatan operasional UKM ini berjalan, sangat disayangkan dalam hal pembukuan masih belum terkoordinir dengan baik dalam pencatatan keuangan yang tertib, dan terarah serta kurangnya pemisahan antara kebutuhan pribadi dan kepentingan bisnis. Berdasarkan hal tersebut, kami tertarik untuk melakukan survei dan membuat rancangan program pengabdian masyarakat dengan judul : "Implementasi Pembukuan Sederhana Pada Umkm Anna Collection Di Desa Pangkalan Kecamatan Plered Kabupaten Cirebon". Dengan adanya Pendampingan yang dilakukan oleh Kami, besar harapan bagi UKM Ana Collection untuk bisa menyusun laporan keuangan khususnya pembukuan yang lebih terarah dimasa yang akan datang.

\section{LANDASAN TEORI}

\subsection{Pemberdayaan Masyarakat}

Secara etimologis pemberdayaan berasal dari kata dasar "daya" yang berarti kekuatan atau kemampuan. Bertolak dari pengertian tersebut, maka pemberdayaan dimaknai sebagai proses untuk memperoleh daya, kekuatan atau kemampuan, dan atau proses pemberian daya, kekuatan atau kemampuan dari pihak yang memiliki daya kepada pihak yang kurang atau belum berdaya (Sulistiyani, 2004). Pemberdayaan dapat diartikan pula sebagai upaya untuk memberikan daya (empowerment) atau penguatan kepada masyarakat (Mas'oed, 1993).

Tujuan utama adanya pemberdayaan masyarakat yaitu untuk memberdayakan masyarakat agar dapat lebih mandiri dan dapat meningkatkan kemampuannya dalam memperbaiki kualitas kehidupan mereka melalui tindakan mereka sendiri (Nugroho et al., 2014). Hal ini menunjukan bahwa konsep pemberdayaan selalu dihubungakan dengan kamandirian, partisipasi, jaringan kerja dan keadilan (Hikmat, 2010; Mardikanto \& Soebiato, 2012).

\subsubsection{Ciri-ciri Pemberdayaan Masyarakat}

Ciri-ciri pemberdayaan masyarakat adalah sebagai berikut :

a) Community leader: petugas kesehatan melakukan pendekatan kepada tokoh masyarakat atau pemimpin terlebih dahulu. Misalnya Camat, lurah, kepala adat, ustad, dan sebagainya. 
b) Community organization: organisasi seperti PKK, karang taruna, majlis taklim,dan lainnnya merupakan potensi yang dapat dijadikan mitra kerja dalam upaya pemberdayaan masyarakat.

c) Community Fund: Dana sehat atau Jaminan Pemeliharaan Kesehatan Masyarakat (JPKM) yang dikembangkan dengan prinsip gotong royong sebagai salah satu prinsip pemberdayaan masyarakat.

d) Community material : setiap daerah memiliki potensi tersendiri yang dapat digunakan untuk memfasilitasi pelayanan kesehatan. Misalnya, desa dekat kali pengahsil pasir memiliki potensi untuk melakukan pengerasan jalan untuk memudahkan akses ke puskesmas.

e) Community knowledge: pemberdayaan bertujuan meningkatkan pengetahuan masyarakat dengan berbagai penyuluhan kesehatan yang menggunakan pendekatan community based health education.

f) Community technology: teknologi sederhana di komunitas dapat digunakan untuk pengembangan program kesehatan misalnya penyaringan air dengan pasir atau arang.

\subsubsection{Tujuan Pemberdayaan Masyarakat}

Menurut Mardikanto (2014), terdapat enam tujuan pemberdayaan masyarakat yaitu:

a. Perbaiki Kelembagaan "Better Institution"

Dengan perbaikan kegiatan/tindakan yang dilakukan, diharapkan akan memperbaiki kelembagaan, termasuk pengembangan jejaring kemitra usaha.

b. Perbaiki Usaha "Better Business"

Perbaikan pendidikan "semangat belajar", perbaikan aksesibisnislitas, kegiatan dan perbaikan kelembagaan, diharapkan akan memperbaiki bisnis yang dilakukan

c. Perbaiki Pendapatan "Better Income"

Dengan terjadinya perbaikan bisnis yang dilakukan diharapkan akan dapat memperbaiki pendapatan yang diperolehnya, ternasuk pendapatan keluarga dan masyarakat.

d. Perbaiki Lingkungan "Better Environment"

Perbaikan pendapatan diharapkan dapat memperbaiki lingkungan "fisik dan social" karena kerusakan lingkungan seringkali disebabkan oleh kemiskinan atau pendapatan yang terbatas.

e. Perbaiki Kehidupan "Better Living"

Tingkat pendapatan dan keadaan lingkungan yang membaik, diharapkan dapat memperbaiki keadaan kehidupan setiap keluarga dan masyarakat.

f. Perbaiki Masyarakat "Better Community"

Kehidupan yang lebih baik didukung oleh lingkungan "fisik dan social" yang lebih baik diharapkan akan terwujud ke kehidupan masyarakat yang lebih baik pula.

\subsection{Pembukuan Sederhana}

Pembukuan sederhana adalah proses dokumentasi yang dilakukan secara terstruktur demi menghimpun data dan laporan transaksi keuangan. Dokumentasi keuangan yang dicatat antara lain kekayaan, beban, modal, pendapatan, anggaran, dan akumulasi harga penghasilan dan pelimpahan barang atau jasa.

\subsubsection{Metode Umum dalam Pembukuan}




\section{PORTAL RISET DAN INOVASI PENGABDIAN MASYARAKAT (PRIMA) \\ VOLUME 1 ISSUE 1 (2021)}

Ada 2 metode umum untuk mencatat pembukuan dalam ilmu akuntansi yaitu sistem pembukuan input tunggal dan sistem berpasangan.

a. Sistem pembukuan masukan tunggal

Sistem ini biasa digunakan di bisnis kecil dan menengah. Metode ini efektif untuk perusahaan yang melakukan transaksi sederhana dan nominalnya kecil. Sumber pembukuan yang digunakan yaitu buku kas utama. Sistem masukan tunggal ini memiliki sifat yang mirip seperti rekening koran. Tidak ada pengelompokan khusus untuk setiap pos pengeluaran dan pemasukan.

b. Sistem pembukuan masukan berpasangan

Sistem masukan berpasangan ini lebih sering digunakan oleh perusahaan berskala besar. Masukan berpasangan ini dinilai lebih baik dibandingkan dengan masukan tunggal. Tersedia akun khusus untuk pemasukan (debit) dan pengeluaran (kredit) yang terpisah. Sehingga akuntan dan perusahaan lebih mudah dalam memantau arus keuangan yang kompleks.

\subsubsection{Jenis-Jenis Pembukuan Sederhana}

Terdapat 3 jenis pembukuan sederhana yaitu pembukuan inventaris barang, catatan kas, dan persediaan (Nuraini \& Andrianto, 2020).

a. Pembukuan Inventaris Barang

Pembukuan inventaris barang berisi catatan semua aset yang dimiliki oleh perusahaan. Aset ini bisa didapatkan dari pembelian maupun hibah. Tujuannya yaitu untuk mempermudah pengawasan terhadap harta perusahaan dan mencegah penyalahgunaannya. Setiap barang yang dimiliki perusahaan diberi nomor tertentu kemudian didokumentasikan dalam pembukuan.

b. Pembukuan Catatan Kas

Pembukuan catatan kas lebih umum disebut sebagai buku kas. Fungsinya adalah untuk mendokumentasikan segala transaksi keluar dan masuk yang dilakukan oleh perusahaan. Sumbernya berasal dari bukti transaksi berupa faktur atau kuitansi. Buku kas inilah yang menjadi acuan dalam pembuatan laporan keuangan dalam satu periode tertentu.

c. Pembukuan Persediaan

Pembukuan persediaan berguna untuk mencatat seluruh barang yang masih tersedia. Catatan ini sangat bermanfaat dalam kegiatan penjualan yang dilakukan oleh perusahaan. Fungsi utama dari pembukuan persediaan yaitu memastikan stok barang masih aman. Perusahaan akan mengetahui waktu yang tepat untuk melakukan re-strok dengan melihat catatan dalam pembukuan persediaan.

\subsubsection{Manfaat Pembukuan Bisnis}

Berikut ini beberapa manfaat yang bisa didapatkan dengan menerapkan pembukuan dalam bisnis yang dijalani.
a. Mengetahui Besaran Laba dan Rugi
b. Memahami setiap transaksi keluar dan masuk
c. Bahan Evaluasi untuk pengembangan bisnis.

\section{METODE PENELITIAN}




\subsection{Solusi Yang Ditawarkan}

Mengacu pada permasalahan yang ditemukan pada UMKM mitra, program ini memberikan alternatif solusi yang dijelaskan pada tabel dibawah ini

Tabel 1 Solusi Permasalahan yang Ditawarkan

\begin{tabular}{|c|l|l|}
\hline Dimensi Prioritas & \multicolumn{1}{|c|}{ Permasalahan } & \multicolumn{1}{|c|}{ Solusi yang ditawarkan } \\
\hline \multirow{2}{*}{ Keuangan } & 1. Belum ada pencatatan keuangan yang tertib dan disiplin & $\begin{array}{l}\text { Pendampingan dan pelatihan } \\
\text { pencatatan keuangan sederhana dan } \\
\text { manajemen biaya untuk memperluas } \\
\text { kesempatan memperoleh pencatatan } \\
\text { keuangan yang dapat memisahkan } \\
\text { antara pembukuan sederhana milik } \\
\text { pribadi dan usaha yang digeluti }\end{array}$ \\
\cline { 2 - 3 } & 3. Perhitungan kas masuk dan kas keluar & \\
\hline
\end{tabular}

\subsection{Target Luaran}

Melalui kegiatan pengadian kepada masyarakat ini diharapkan dapat mencapai target luaran yaitu :
a. Satu artikel ilmiah
b. Video kegiatan; dan
c. Peningkatan keberdayaan mitra sesuai permasalahan yang dihadapi

\subsection{Jadwal Kegiatan Program Kemitraan Masyarakat}

Jadwal Program Kemitraan Masyarakat yang diajukan diuraikan dalam tabel berikut ini :

Tabel 2 Jadwal Kegiatan Program Kemitraan Masyarakat

\begin{tabular}{|c|c|c|c|c|c|c|c|c|}
\hline \multirow{2}{*}{ Kegiatan } & \multicolumn{8}{|c|}{ Bulan } \\
\hline & Juni & Juli & Agust & Sept & Okt & Nop & Des & Jan \\
\hline $\begin{array}{l}\text { Survei Lokasi Mitra } \\
\text { Binaan }\end{array}$ & & & & & & & & \\
\hline $\begin{array}{l}\text { Finalisasi Program } \\
\text { Kemitraan } \\
\text { Masyarakat }\end{array}$ & & & & & & & & \\
\hline $\begin{array}{l}\text { Kegiatan } \\
\text { Pendampingan Mitra } \\
\text { Binaan }\end{array}$ & & & & & & & & \\
\hline $\begin{array}{l}\text { Evaluasi Program } \\
\text { Kemitraan } \\
\text { Masyarakat }\end{array}$ & & & & & & & & \\
\hline $\begin{array}{l}\text { Pelaporan Program } \\
\text { Kemitraan } \\
\text { Masyarakat }\end{array}$ & & & & & & & & \\
\hline
\end{tabular}




\section{PORTAL RISET DAN INOVASI PENGABDIAN MASYARAKAT (PRIMA) \\ VOLUME 1 ISSUE 1 (2021)}

\subsection{Anggaran Biaya}

Anggaran biaya Program Kemitraan Masyarakat yang diajukan diuraikan dalam tabel berikut ini :

Tabel 3 Anggaran Biaya Program Kemitraan Masyarakat yang diajukan

\begin{tabular}{|c|l|r|}
\hline No & \multicolumn{1}{|c|}{ Komponen } & $\begin{array}{c}\text { Biaya yang } \\
\text { Diusulkan (Rp) }\end{array}$ \\
\hline 1 & Honorarium pelaksanaan pengabdian (Maksimal 30\%) & Rp. 2.250.000 \\
\hline 2 & $\begin{array}{l}\text { Pembelian bahan habis pakai untuk ATK, foto copy, surat menyurat, } \\
\text { penyusunan laporan, jilid laporan, publikasi, pembelian bahan. } \\
\text { (maksimal 45\%) }\end{array}$ & Rp. 3.375.000 \\
\hline 3 & $\begin{array}{l}\text { Perjalanan kegiatan pengabdian, biaya akomodasi, transport } \\
\text { (maksimal 20\%) }\end{array}$ & Rp.1.500.000 \\
\hline 4 & Pemantauan Internal, (maksimum 5\%) & Rp. 375.000 \\
\hline \multicolumn{2}{|c|}{ Jumlah } & Rp.500.000 \\
\hline
\end{tabular}

\section{HASIL DAN PEMBAHASAN}

\subsection{Pelaksanaan Kegiatan PKM}

Kegiatan pengabdian dilakukan di Desa Pangkalan kecamatan Plered kabupaten Cirebon dengan pertemuan-pertemuan secara langsung dengan mitra dan juga melalui media komunikasi serta memberikan respon positif terhadap UMKM Ana Collection mengenai usaha yang dijalankan yaitu penjualan baju Muslim yang mana pangsa pasar terbatas pada daerah sekitar saja. Aktifitas kegiatan yang dilakukan dalam proses pengabdian yang dilakukan adalah sebagai berikut :

Survey yang dilakukan pada tanggal 9 juni 2021 yaitu dengan bertemu dengan Pemilik utama dari UMKM Ana Collection terlebih dahulu untuk meminta ijin dan berdiskusi mengenai usaha yang dijalani kemudian menanyakan apa saja kendala yang dihadapi selama menjalankan bisnis tersebut. Setelah mendapatkan informasi yang cukup mengenai Permasalahan yang dihadapi. Pada tanggal 7 juli 2021, kami memulai program pengabdian yaitu berupa pemberian pelatihan tentang bagaimana membuat suatu pembukuan yaitu pembukuan sederhana pada UMKM Ana Collection.

Pelatihan diberikan dengan memberikan penjelasan dan contoh contoh formulir/buku pencatatan laporan keuangan dalam bentuk bulanan yang sesuai standard dan sesederhana mungkin yang dapat dipahami oleh Mitra, dengan harapan setelah diadakannya pelatihan ini, mitra dapat mengaplikasikannya untuk membuat pembukuan sederhana dalam bentuk baik harian maupun bulanan.

Gambar berikut merupakan kegiatan pelatihan dan penjelasan yang dilakukan oleh kami mengenai bagaimana cara membuat catatan pembukuan sederhana untuk UMKM Ana Collection. 

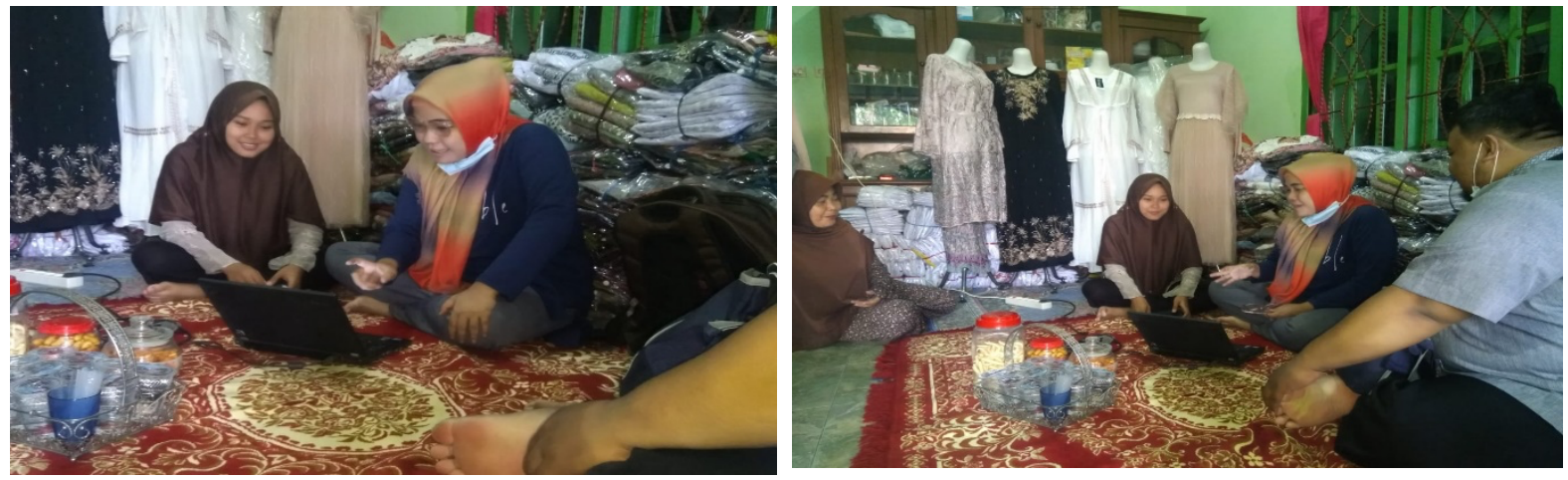

Gambar 1 kegiatan Pelatihan pembukuan sederhana

Pendampingan dilakukan baik secara langsung maupun melalui media Online untuk memastikan mitra dapat menjalankan kegiatan tata kelola keuangan melalui pembukuan sederhana dengan baik dan benar serta dapat memahaminya dan pada akhirnya dapat menjalankannya.

Monitoring dilakukan untuk melihat sejauh mana pemahaman dan realisasi dari arahan dan pembelajaran yang diberikan oleh pendamping.

\subsection{Hasil yang dicapai}

Pelaksana membantu dan mengarahkan mitra dalam mengidentifikasi transaksi yang berkaitan dengan usaha, sehingga mitra dapat mengidentifikasi antara kas pribadi dengan kas usaha selain itu juga, pelaksana memberikan pemahaman mengenai pencatatan kas masuk dan kas keluar baik secara tunai maupun secara kredit.

Pelaksana memberikan contoh cara mencatat uang masuk dan uang keluar bai tunai maupun kredit dan diikuti oleh mitra, kemudian memberikan contoh melakukan pembuatan pencatatan transaksi harian selama satu bulan.

Setelah melakukan pendampingan, Mitra " Ana Collection " sudah dapat memisahkan antara kas hasil usaha dengan kas pribadi serta dapat melakukan pencatatan harian sesuai dengan nota baik pembelian maupun pemasukan selama satu bulan.

\section{KESIMPULAN}

Pembukuan sederhana merupakan hal yang sangat penting didalam dunia Bisnis, banyak sekali manfaat yang di dapat apabila sebuah UMKM memiliki pembukuan yang teratur. Selain dapat digunakan sebagai patokan untuk melihat keuntungan yang didapat, dengan adanya pembukuan juga dapat pula para pebisnis mengetahui kerugian yang dialaminya. Serta dengan adanya pembukuan, maka pelaku usaha dapat pula mengukur keberhasilan dalam berusaha dari waktu kewaktu serta dapat melakukan evaluasi usahanya dimasa yang akan datang.

Pendampingan pembuatan pembukuan sederhana sangat diperlukan bagi para pelaku usaha, karena manfaat yang didapat sangatlah banyak, selain yang telah dijelaskan diatas, manfaat yang diperoleh pelaku bisnis adalah mendapatkan bantuan pinjaman untul modal usahanya. 


\section{Saran}

Saran yang dapat diberikan untuk pelaku UMKM khususnya "Ana Collection" adalah adanya keberlanjutan dari kegiatan pendampingan ini dan dilaksanakannya secara langsung bagi pelaku usaha UMKM yang lainnya

\section{DAFTAR PUSTAKA}

Gintings, A. (2011). Essensi Praktis Manajemen Pendidikan dan Pelatihan. Humaniora.

Hikmat, R. H. (2010). Strategi Pemberdayaan Masyarakat Edisi Revisi. Humaniora Bandung (ID): Utama Pres.

Mardikanto, T. (2014). CSR (Corporate Social Responsibility) (Tanggungjawab Sosial Korporasi). Alfabeta.

Mardikanto, T., \& Soebiato, P. (2012). Pemberdayaan masyarakat dalam perspektif kebijakan publik. Alfabeta.

Mas'oed. (1993). Ekonomi Politik Pembangunan dan Pemberdayaan Masyarakat. Dalam Prospektif, 5(2).

Nugroho, A., Daru, A. F., \& Adhiwibowo, W. (2014). Pengembangan Pemasaran Online Usaha Kerajinan Enceng Gondok dan Pandan di Desa Lopait Kecamatan Tuntang Kabupaten Semarang. Jurnal Transformatika, 12(1). https://doi.org/10.26623/transformatika.v12i1.87

Nuraini, F., \& Andrianto, A. (2020). Kewirausahaan dan Pembukuan (Sebuah Kajian Pengabdian Masyarakat). http://repository.um-surabaya.ac.id/5404/

Sulistiyani, A. T. (2004). Kemitraan dan Model-Model Pemberdayaan. Gava Media. 